Available online on 15.07.2017 at http://jddtonline.info
Journal of Drug Delivery and Therapeutics
Open Access to Pharmaceutical and Medical Research
$\begin{gathered}\text { (2011-17, publisher and licensee JDDT, This is an Open Access article which permits unrestricted } \\ \text { noncommercial use, provided the original work is properly cited }\end{gathered}$

Open $\odot$ Access

Re search Article

\title{
HYPOGLYCAEMIC ACTIVITY OF CENTRATHERUM ANTHELMINTICU IN EXPERIMENTAL ANIMALS
}

\author{
Ramji Swarnkar $^{* 1}$, Dr. Chandrul Kaushal ${ }^{1}$, DR. S.K. Jain ${ }^{2}$ \\ ${ }^{1}$ Institute of Pharmacy, Shri Venkateshwara University, Gajroula, Uttar Pradesh, India \\ ${ }^{2}$ Institute of Pharmacy, Bundelkhand University, Jhansi, India
}

\section{ABSTRACT}

The Effect of Ethanolic extracts of Centratherum anthelminticum on Diabetic rats Assessment of the antihyperglycemic effect of ethanolic extract of Centratherum anthelminticum seeds in normal and alloxan induced diabetic rats: The animals will be divided into nine groups and each group consisted of six rats. Group 1 as normal control. Group 2 as the diabetic control. Groups 3, 4 and 5 are normally treated with $0.25 \mathrm{~g}, 0.50 \mathrm{~g}$ and $0.75 \mathrm{~g} / \mathrm{kg} \mathrm{BW}$ of CAEt, respectively. Groups 6,7 and 8 are diabetic rats treated with $0.25 \mathrm{~g}, 0.50 \mathrm{~g}$, and $0.75 \mathrm{~g} / \mathrm{kg}$ BW of CAEt, respectively. Group 9 are diabetic rats which received glibenclamide $(0.02 \mathrm{~g} / \mathrm{kg} \mathrm{BW})$ an oral hypoglycemic agent dissolved in distilled water. Normal control and the diabetic control rats are fed distilled water alone. After an overnight fast, the plant extract suspended in distilled water will feed to the rats by gastric intubation using a force feeding needle. Blood samples are collected for the measurement of blood glucose from the tail vein at $0,1,2,3,4,5$ and $6 \mathrm{~h}$ after the administration of plant extract and blood glucose levels are determined by Glucose oxidase - peroxidase method. The phytochemical analysis will be carried out in the ethanolic extract by different methods of phytochemical analysis.

Keywords: Hypoglycaemia, Diabetes mellitus, Centratherum anthelminticum

Article Info: Received 28 May, 2017; Review Completed 13 July, 2017; Accepted 14 July, 2017; Available online 15 July, 2017

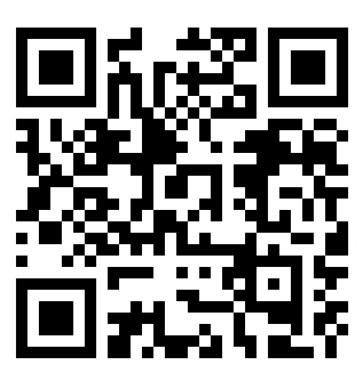

Cite this article as:

Swarnkar R., Kaushal C., Jain S.K., Hypoglycaemic activity of Centratherum anthelminticu in experimental animals, Journal of Drug Delivery and Therapeutics. 2017; 7(4):73-77

DOI: http://dx.doi.org/10.22270/jddt.v7i4.1472

*Address for Correspondence

Ramji Swarnkar, Institute of Pharmacy, Shri Venkateshwara University, Gajroula, Uttar Pradesh, India Email: ramjisoni2004@yahoo.com

\section{INTRODUCTION}

Diabetes mellitus (DM) is a common metabolic disorder affecting people in both developed and developing countries. Diabetes can be divided into two main groups based on their requremantly for insulin. Insulin dependent diabetes mellitus (type 1) and non insulin dependent diabetes mellitus (type 2) the disease is characterized by chronic hyperglycemia, which is not effectively controlled can cause blindness, kidney failure or nerve damage. Type 2 diabetes is the most prevalent and accounts for approximately $90 \%$ of cases of diabetes mellitus worldwide and characterized by a combination of defects in insulin secretion and insulin sensitivity ${ }^{7}$. Glycaemic control is one of the targets for managing DM. studies have developing complications of diabetes ${ }^{4}$.
The main side effects of insulin therapy and oral hypoglycemic agents necessitate a search for more effective and safer anti diabetic drugs ${ }^{3}$. Scientific search for hypoglycemic agents from medicinal plants as recommended by the world health organization (WHO expert committee 1980) has even more important in the last few decades. Over 500 herbal medicines have been reported to possess anti diabetic property ${ }^{2}$. Diabetes mellitus is one of the disease for which a satisfactory treatment is not available in modern allopathic system of medicine ${ }^{6}$. Therefore the search for an ideal drug for the treatment of diabetes containing and has been extended to herbs. Centratherum anthelminticum is an important drug of indigenous system of medicine and has been know for a number of medicinal properties in ayurveda ${ }^{4}$. 
Centratherum anthelminticum is used as the folk medicine for diabetes in Rayalaseema of Andhra Pradesh of India.

\section{MATERIAL AND METHOD}

\section{Plant materials collection}

The fresh seeds of Centratherum anthelminticum (Wild) Kuntze; Family Asteaceae were obtained from the commercial sources and identified and authntified by dr. Rakesh kumar Tewari Professor \& Head Department of Dravyaguna Bundelhand Government Ayurvedic College \& Hospital Jhansi (U.P.) India sample was submitted in the museum (sample no.001A)

\section{Drug and chemical}

\section{Preparation of extract}

All the chemicals were analytical grade. Standard kit of RIA serum insulin level, GOD,-POD kit serum glucose level, other biochemical kits were obtained from was obtained from anmol pharma Jaipur (Rajasthan)

The dried seed were grinded and $500 \mathrm{gm}$ of seed powder was soaked in ethanol (2L; 95\%) for overnight at room temperature. Then filtered through Whatmann paper No.42 $(125 \mathrm{~mm})$ filter paper twice and concentrated at $40^{\circ} \mathrm{C}$ till dryness in a rotary vacuum evaporator. Finally obtained brown residue termed as ethanolic seed (extract CTEt) that was stored in refrigerator below $10^{\circ}$ until used $^{5}$

\section{Experimental animals}

Healthy Swiss albino rats weighing about (180-250gm) of either sex were obtained from animal house, institute of pharmacy, Bundelkhand university jhansi. The animals were housed in specific standard laboratory conditions. The conditions were kept in a tempretaurecontrolled environment $\left(25 \pm 1^{\circ} \mathrm{c}\right)$ and with a regular $12 \mathrm{~h}$ light/12hr dark cycle. All animals were fed with commercial diet and water during experiment. All protocols of the study were approved by instititional animal ethical committee with reference number BU/PHARM/IAEC/12/O42. The IAEC is approved by committee for the purpose of control and supervision of experiments of animals (CPCSEA) with registration number 716/02/a/CPCSEA.

\section{Experiment and Group of Rats}

The animals will be divided in to nine groups and each group consisted of six rats. Group 1 as normal control. Group 2 as the diabetic control. Groups 3, 4 and 5 are normal treated with $0.25 \mathrm{~g}, 0.50 \mathrm{~g}$ and $0.75 \mathrm{~g} / \mathrm{kg}$ bw of CAEt, respectively. Groups 6, 7 and 8 are diabetic rats treated with $0.25 \mathrm{~g}, 0.50 \mathrm{~g}$ and $0.75 \mathrm{~g} / \mathrm{kg}$ bw of CAEt, respectively. Group 9 are diabetic rats which received glibenclamide $(0.02 \mathrm{~g} / \mathrm{kg} \mathrm{bw})$ an oral hypoglycemic agent dissolved in distilled water. Normal control and the diabetic control rats are fed distilled water alone. After an overnight fast, the plant extract suspended in distilled water will fed to the rats by gastric intubation using a force feeding needle. Blood samples are collected for the measurement of blood glucose from the tail vein at $0,1,2,3,4,5$ and $6 \mathrm{~h}$ after the administration of plant extract and blood glucose levels are determined by Glucose oxidase - peroxidase method.

Phytochemical analysis will carried out in the ethanolic extract by different methods of phytochemical analysis.

\section{Induction of Diabetes}

In humans, diabetes mellitus is one of the most prevalent conditions with spontaneous manifestation. In animals, it can be induced by partial pancreatectomy or by the administration of diabetogenic drugs such as alloxan, streptozotocin, ditizona and anti-insulin serum. These agents selectively destroy the Langerhans islet $B$-cells. The best known drug-induced diabetes model is the alloxan diabetes. Alloxan, a derivative of uric acid, as well as of other substances of different chemical groups, cases B-cells to degranulate and consequently degenerate. Alloxan induces irreversible diabetes mellitus after 24 hours following its administration and the condition proves to be chronic by laboratory tests after seven days. After a 48- hour fast, the rats are weighed and anesthetized by inhalation in a glass dome. A solution of alloxan at $2 \%$ diluted in saline at $0.9 \%$ will administered to the animals in a single dose corresponding to $40 \mathrm{mg}$ of alloxan per $\mathrm{kg}$ of animal weight injected in to their penial vein ${ }^{1}$.

\section{Evaluation of Biochemical Parameters}

Estimation of serum glucose level (GOD-POD method), serum insulin level (RIA method), serum cholesterol (enzymatic method), HDL cholesterol (enzymatic method), serum triglyceride (enzymatic method), serum urea (berthelot method) and creatinine (alkaline picrate method) will be estimate. VLDL-cholesterol and LDLcholesterol are calculated as per Friedewald' equation.

VLDL-cholesterol $=$ total serum triglycerides $/ 5$

LDL-cholesterol $=$ Total serum cholesterol- total serum triglycerides/5-HDL-C

\section{Statistical Analysis}

Results were presented as mean SEM. Statistical differences between the means of the various groups were evaluated using one-way analysis of variance followed by turkey's multiple parametric tests. Data were considered statistically significant at $\mathrm{P}$ value $\leq 0.05$ and highly significant at $P$ 0.001. Statistical analysis was performed using Sigma stat statistical software (Ver.2.03). 


\section{RESULTS}

Table 1: Effect of ethanolic extract CAEt treatment on general features of diabetic rats.

\begin{tabular}{|l|l|l|l|l|l|l|l|l|l|}
\hline Parameter & $\begin{array}{l}\text { Group1 } \\
\mathrm{n}=6\end{array}$ & $\begin{array}{l}\text { Group2 } \\
\mathrm{n}=6\end{array}$ & $\begin{array}{l}\text { Group3 } \\
\mathrm{V}\end{array}$ & $\begin{array}{l}\text { Group4 } \\
\mathrm{n}=6\end{array}$ & $\begin{array}{l}\text { Group5 } \\
\mathrm{n}=6\end{array}$ & $\begin{array}{l}\text { Group6 } \\
\mathrm{n}=6\end{array}$ & $\begin{array}{l}\text { Group7 } \\
\mathrm{n}=6\end{array}$ & $\begin{array}{l}\text { Group8 } \\
\mathrm{n}=6\end{array}$ & $\begin{array}{l}\text { Group9 } \\
\mathrm{n}=6\end{array}$ \\
\hline Average Body & 230.30 & $211.32^{* *}$ & 219.50 & 195.20 & 185.50 & 215.25 & $220.20^{*}$ & 212.12 & $230.10^{* * *}$ \\
weight(gm/day) & \pm 0.50 & \pm 2.50 & \pm 2.10 & \pm 1.30 & \pm 2.25 & \pm 1.25 & \pm 1.50 & \pm 1.20 & \pm 1.70 \\
\hline Food & 20.77 & $42.81^{* *}$ & 22.19 & 21.30 & 20.20 & 22.50 & 22.60 & $21.10^{*}$ & $19.90^{* *}$ \\
intake(gm/animal/day & \pm 0.53 & \pm 0.82 & \pm 0.55 & \pm 0.42 & \pm 0.58 & \pm 0.50 & \pm 0.53 & \pm 0.48 & \pm 0.51 \\
\hline Water & 22.21 & $72.22^{* *}$ & $21.22^{*}$ & 22.00 & 28.12 & 62.54 & 62.12 & $61.59^{*}$ & $58.56^{* *}$ \\
intake(ml/animal/day & \pm 0.42 & \pm 1.11 & \pm 0.52 & \pm 0.63 & \pm 0.59 & \pm 0.42 & \pm 0.63 & \pm 0.52 & \pm 2.22 \\
\hline
\end{tabular}

Values are expressed as Mean \pm SEM

** Significantly different control $(\mathrm{p}<0.001)$

* Significantly different from diabetic control $(\mathrm{p}<0.05)$

** Significantly different from diabetic control $(\mathrm{p}<0.001)$

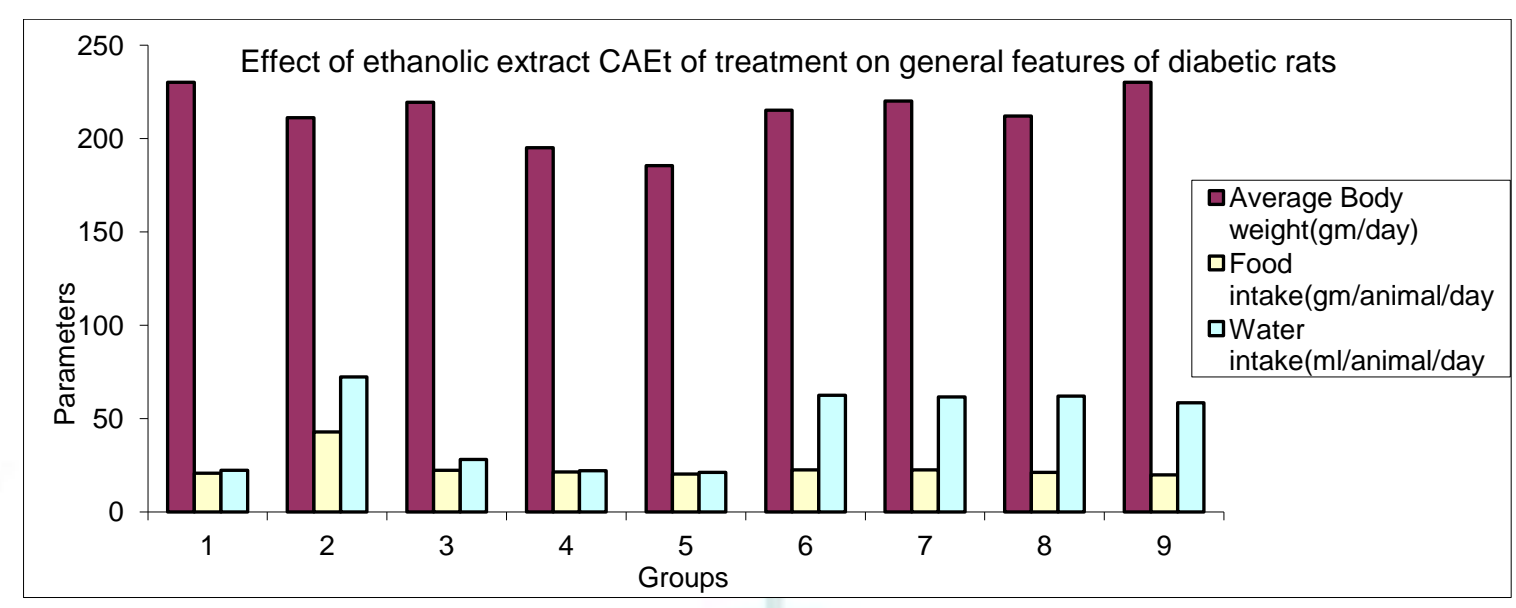

Figure 1: Effect of ethanolic extract CAEt of treatment on general features of diabetic rats

Table 2: Effect of different doses of ethanolic extract of Centratherum anthelminticum on fasting Blood glucose level $(\mathrm{mg} / \mathrm{dl})$ of normal and diabetic rats $($ Mean \pm SEM)

\begin{tabular}{|c|c|c|c|c|c|c|c|}
\hline \multirow[t]{2}{*}{ Treatment } & \multicolumn{7}{|c|}{ Time(Hrs) } \\
\hline & 0Hrs & $1 \mathrm{Hrs}$ & $2 \mathrm{Hrs}$ & $3 \mathrm{Hrs}$ & $4 \mathrm{Hrs}$ & $5 \mathrm{Hrs}$ & $6 \mathrm{Hrs}$ \\
\hline $\begin{array}{l}\text { Group1 } \\
n=6\end{array}$ & $79.59 \pm 2.11$ & $78.15 \pm 2.20$ & $81.31 \pm 1.56$ & $82.10 \pm 2.21$ & $81.51 \pm 1.19$ & $78.61 \pm 2.31$ & $77.43 \pm 1.56$ \\
\hline $\begin{array}{l}\text { Group2 } \\
\mathrm{n}=6\end{array}$ & $272.52 \pm 5.52$ & $278.32 \pm 7.35$ & $276.59 \pm 6.31$ & $277.51 \pm 6.32$ & $272.33 \pm 7.32$ & $271.51 \pm 7.71$ & $272.39 \pm 7.21$ \\
\hline $\begin{array}{l}\text { Group3 } \\
n=6\end{array}$ & $81.12 \pm 1.82$ & $\begin{array}{l}79.74 \pm 1.64 \\
1.7 \%\end{array}$ & $\begin{array}{l}77.91 \pm 1.81 \\
4.0 \%\end{array}$ & $\begin{array}{l}75.12 \pm 2.12 \\
7.4 \%\end{array}$ & $\begin{array}{l}70.19 \pm 2.31^{* * *} \\
13.5 \%\end{array}$ & $\begin{array}{l}67.52 \pm 0.91^{* * * *} \\
16.8 \%\end{array}$ & $\begin{array}{l}74.60 \pm 1.42^{*} \\
8.0 \%\end{array}$ \\
\hline $\begin{array}{l}\text { Group4 } \\
n=6\end{array}$ & $79.23 \pm 1.32$ & $\begin{array}{l}71.82 \pm 2.11 \\
9.4 \%\end{array}$ & $\begin{array}{l}70.12 \pm 1.51 \\
11.5 \%\end{array}$ & $\begin{array}{l}69.21 \pm 1.39 \\
12.6 \%\end{array}$ & $\begin{array}{l}68.01 \pm 1.92^{* * * *} \\
14.2 \%\end{array}$ & $\begin{array}{l}66.91 \pm 1.11^{* * * *} \\
15.5 \%\end{array}$ & $\begin{array}{l}68.21 \pm 2.01^{* * *} \\
13.9 \%\end{array}$ \\
\hline $\begin{array}{l}\text { Group5 } \\
n=6\end{array}$ & $77.71 \pm 1.91$ & $\begin{array}{l}71.01 \pm 2.11 \\
8.6 \%\end{array}$ & $\begin{array}{l}70.03 \pm 1.21 \\
9.9 \%\end{array}$ & $\begin{array}{l}68.11 \pm 2.22 \\
12.4 \%\end{array}$ & $\begin{array}{l}59.22 \pm 1.17^{\text {*N*\% }} \\
23.8 \%\end{array}$ & $\begin{array}{l}54.47 \pm 1.01^{3: * \%} \\
29.9 \%\end{array}$ & $\begin{array}{l}61.99 \pm 1.70^{* * *} \\
.20 .2 \%\end{array}$ \\
\hline $\begin{array}{l}\text { Group6 } \\
n=6\end{array}$ & $268.52 \pm 4.69$ & $\begin{array}{l}260.32 \pm 5.12 \\
3.0 \%\end{array}$ & $\begin{array}{l}258.17 \pm 3.12 \\
3.9 \%\end{array}$ & $\begin{array}{l}252.72 \pm 3.33 \\
5.9 \%\end{array}$ & $\begin{array}{l}247.54 \pm 4.41^{* \%} \\
7.8 \%\end{array}$ & $\begin{array}{l}231.32 \pm 2.22^{* * * * \%} \\
13.6 \%\end{array}$ & $\begin{array}{l}246.12 \pm 2.32^{* * \%} \\
8.3 \%\end{array}$ \\
\hline $\begin{array}{l}\text { Group7 } \\
\mathrm{n}=6\end{array}$ & $272.15 \pm 2.12$ & $\begin{array}{l}251.31 \pm 2.23 \\
7.7 \%\end{array}$ & $\begin{array}{l}236.50 \pm 4.21 \\
13.0 \%\end{array}$ & $\begin{array}{l}212.32 \pm 3.31^{*} \\
22 \%\end{array}$ & $\begin{array}{l}196.92 \pm 3.32^{* * * *} \\
27 \%\end{array}$ & $\begin{array}{l}185.21 \pm 3.12^{* * * *} \\
32 \%\end{array}$ & $\begin{array}{l}180.42 \pm 4.42^{* * * *} \\
33.7 \%\end{array}$ \\
\hline $\begin{array}{l}\text { Group8 } \\
n=6\end{array}$ & $352.40 \pm 8.21$ & $\begin{array}{l}342.52 \pm 7.71 \\
2.8 \%\end{array}$ & $\begin{array}{l}302.82 \pm 8.12 \\
14.0 \%\end{array}$ & $\begin{array}{l}270.62 \pm 3.17 \\
23.2 \%\end{array}$ & $\begin{array}{l}245.32 \pm 6.65^{\text {at: }} \\
30.4 \%\end{array}$ & $\begin{array}{l}225.72 \pm 8.80 \\
35.9 \%\end{array}$ & $\begin{array}{l}212.35 \pm 6.20 \\
39.7 \%\end{array}$ \\
\hline $\begin{array}{l}\text { Group9 } \\
n=6\end{array}$ & $\begin{array}{l}268.31 \pm 11.8 \\
0\end{array}$ & $\begin{array}{l}252.34 \pm 8.91 \\
6.0 \%\end{array}$ & $\begin{array}{l}248.21 \pm 9.61 \\
13.3 \%\end{array}$ & $\begin{array}{l}232.19 \pm 8.76 \\
18.9 \%\end{array}$ & $\begin{array}{l}229.71 \pm 11.90^{*} \\
19.8 \%\end{array}$ & $\begin{array}{l}176.21 \pm 6.63^{* * * *} \\
38.5 \%\end{array}$ & $\begin{array}{l}210.30 \pm 9.16^{* *} \\
26.5 \%\end{array}$ \\
\hline
\end{tabular}

Values in Parenthesis are percentage of decreases in Blood glucose-

$* \mathrm{P}<0.05$ compared with the initial level of blood glucose $(0 \mathrm{~h})$ in the respective group

$* * \mathrm{P}<0.01$ compared with the initial level of blood glucose $(0 \mathrm{~h})$ in the respective group

$* * * \mathrm{P}<0.001$ compared with the initial level of blood glucose $(0 \mathrm{~h})$ in the respective group 


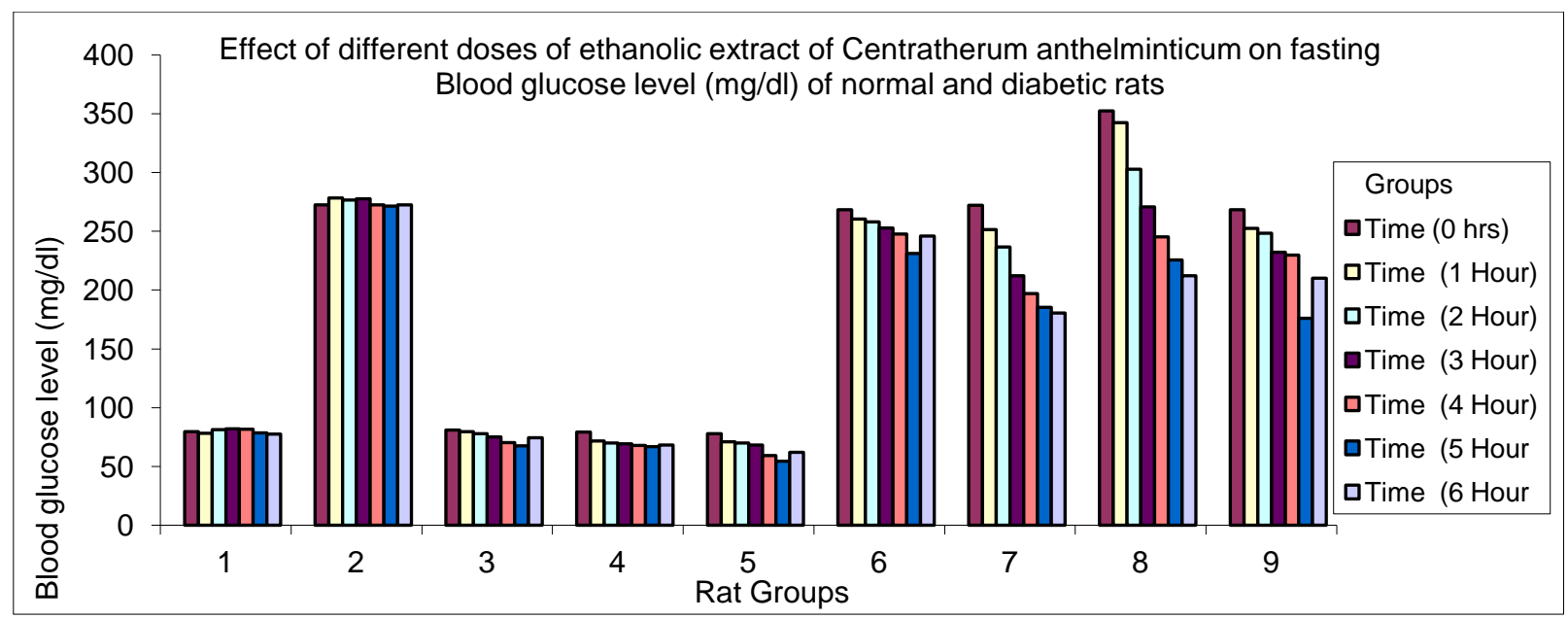

Figure 2: Effect of different doses of ethanolic extract of Centratherum anthelminticum on fasting Blood glucose level (mg/dl) of normal and diabetic rats

Table 3: Effect of ethanolic extract C.A of treatment on biochemical parameters of diabetic rats

\begin{tabular}{|l|l|l|l|l|l|l|l|l|l|}
\hline PARAMETER & $\begin{array}{l}\text { Group1 } \\
\mathrm{n}=6\end{array}$ & $\begin{array}{l}\text { Group2 } \\
\mathrm{n}=6\end{array}$ & $\begin{array}{l}\text { Group3 } \\
\mathrm{n}=6\end{array}$ & $\begin{array}{l}\text { Group4 } \\
\mathrm{n}=6\end{array}$ & $\begin{array}{l}\text { Group5 } \\
\mathrm{n}=6\end{array}$ & $\begin{array}{l}\text { Group6 } \\
\mathrm{n}=6\end{array}$ & $\begin{array}{l}\text { Group7 } \\
\mathrm{n}=6\end{array}$ & $\begin{array}{l}\text { Group8 } \\
\mathrm{n}=6\end{array}$ & $\begin{array}{l}\text { Group9 } \\
\mathrm{n}=6\end{array}$ \\
\hline Total & 79.20 & $104.52^{*}$ & 81.37 & 82.44 & 84.37 & $87.55^{*}$ & $90.41^{*}$ & 91.37 & $87.90^{*}$ \\
cholesterol$(\mathrm{mg} / \mathrm{dl})$ & \pm 6.26 & \pm 1.4 & \pm 4.23 & \pm 3.31 & \pm 5.24 & \pm 4.41 & \pm 4.44 & \pm 4.53 & \pm 5.55 \\
\hline HDL & 45.08 & $25.67^{* *}$ & 40.05 & 41.07 & 42.06 & 30.39 & 31.72 & 31.62 & $36.01^{*}$ \\
cholesterol$(\mathrm{mg} / \mathrm{dl})$ & \pm 2.48 & \pm 2.4 & \pm 3.32 & \pm 4.79 & \pm 3.78 & \pm 2.20 & \pm 3.20 & \pm 1.41 & \pm 2.68 \\
\hline LDL & 19.35 & $54.33^{* *}$ & 21.32 & 22.47 & 24.33 & 41.23 & 42.37 & $40.61^{*}$ & $32.82^{* *}$ \\
cholesterol$(\mathrm{mg} / \mathrm{dl})$ & \pm 6.21 & \pm 1.32 & \pm 5.51 & \pm 4.42 & \pm 3.41 & \pm 3.30 & \pm 2.21 & \pm 4.16 & \pm 4.04 \\
\hline VLDL & 17.14 & $26.54^{* *}$ & 19.27 & 22.42 & 21.72 & 22.22 & 21.47 & $21.26^{*}$ & $20.06^{*}$ \\
cholesterol(mg/dl) & \pm 1.21 & \pm 1.34 & \pm 1.37 & \pm 3.48 & \pm 3.17 & \pm 2.36 & \pm 3.12 & \pm 0.52 & \pm 0.72 \\
\hline Serum & 82.75 & $126.51^{* *}$ & 84.57 & 84.58 & 85.79 & 106.40 & 105.46 & 104.31 & $96.48^{*}$ \\
Triglyceride(mg/dl) & \pm 3.01 & \pm 6.67 & \pm 2.27 & \pm 2.74 & \pm 2.23 & \pm 2.29 & \pm 3.37 & \pm 3.21 & \pm 4.50 \\
\hline Serum & 1.06 & $1.35^{*}$ & 1.05 & 1.05 & 1.07 & $1.03^{*}$ & 1.31 & 1.28 & $1.12^{*}$ \\
Creatinine(mg/dl) & \pm 0.07 & \pm 0.03 & \pm 0.06 & \pm 0.04 & \pm 0.05 & \pm 0.03 & \pm 0.07 & \pm 0.02 & \pm 0.08 \\
\hline Serum & 45.91 & $91.31^{* *}$ & 46.92 & 48.28 & 50.47 & 70.23 & 72.48 & $68.45^{*}$ & $67.73^{*}$ \\
Urea $(\mathrm{mg} / \mathrm{dl})$ & \pm 0.77 & \pm 6.07 & \pm 0.79 & \pm 1.12 & \pm 2.31 & \pm 1.20 & \pm 2.76 & \pm 2.58 & \pm 7.60 \\
\hline
\end{tabular}

Values are expressed as Mean \pm SEM

* Significantly different from normal control $(\mathrm{p}<0.05)$

** Significantly different from normal control $(\mathrm{p}<0.001)$

* Significantly different from diabetic control $(\mathrm{p}<0.05)$

** Significantly different from diabetic control $(\mathrm{p}<0.001)$

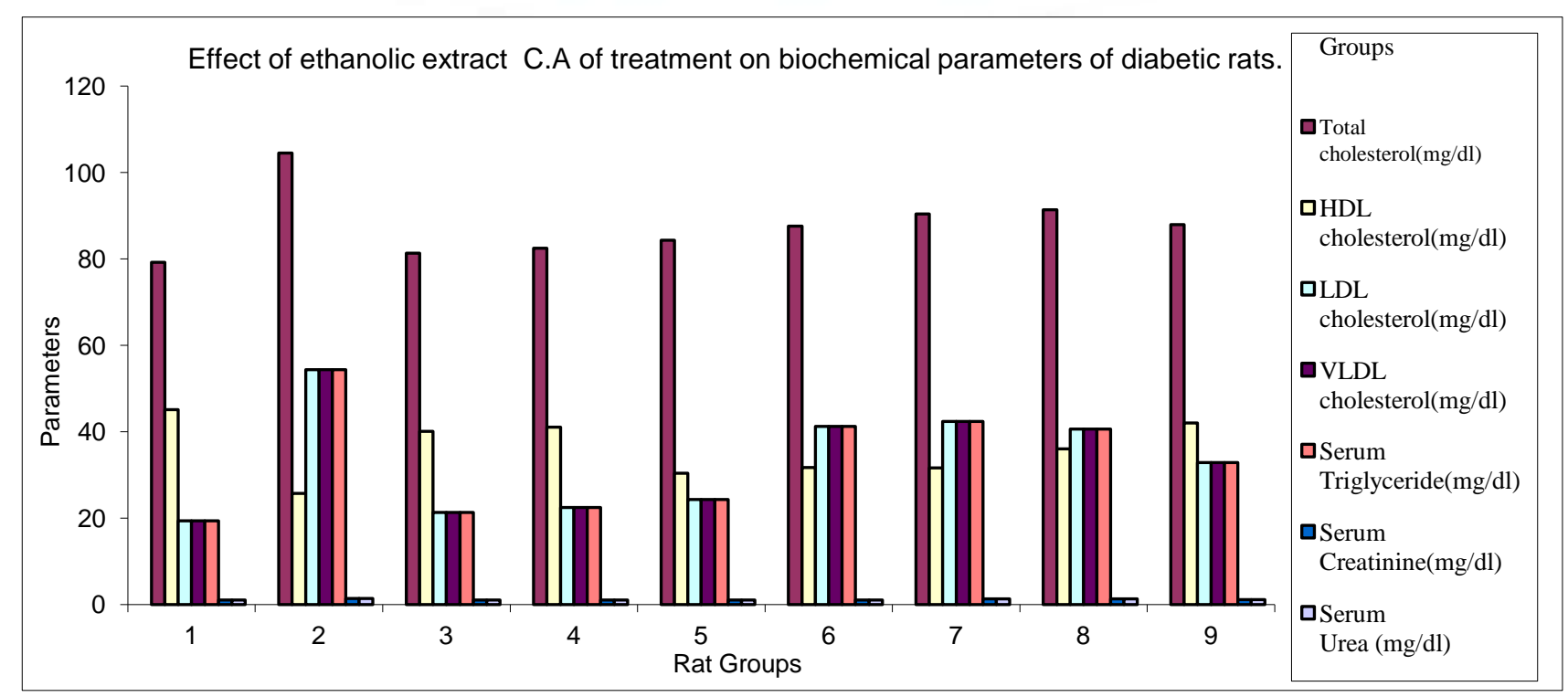

Figure 3: Effect of ethanolic extract C.A of treatment on biochemical parameters of diabetic rats 


\section{DISCUSSION AND CONCLUSION}

Intravenous injection of Alloxan in a single dose corresponding to $40 \mathrm{mg}$ of alloxan per $\mathrm{kg}$ of animal weight injected into their penial vein produced cardinal signs of type1 diabetes i.e. loss of body weight, polyphagia, and polydipsia.(Table-1) chronic treatment with ethanolic extract of $\mathrm{CA}(0.75 \mathrm{~g} / \mathrm{kg} / \mathrm{p} .0 . / 20$ days $)$ was found to prevent the loss of body weight $\left(212.12 \pm 1.20 \mathrm{gm} / \mathrm{animal} / \mathrm{day}\right.$ group $8^{\text {th }}$ Vs $211.32 \pm 2.50$ gm /animal/day group $2^{\text {nd }}$ ) and significantly decreases the food intake $\left(21.10 \pm 0.48 \mathrm{gm} / \mathrm{animal} /\right.$ day group $8^{\text {th }} \mathrm{Vs}$ $42.81 \pm 0.82 \mathrm{gm} /$ animal $/$ day group $2^{\text {nd }}$ ) and water intake $\left(61.59 \pm 0.52 \mathrm{ml} / \mathrm{animal} /\right.$ day group ${ }^{\text {th }} \mathrm{Vs} 72.22 \pm 1.11 \mathrm{ml}$ /animal/day group $2^{\text {nd }}$ ) as compare to group $2^{\text {nd }}$. Group $3,4,5$, compare with group1slightly change in body weight, food intake and water intake.

The effect of different doses of the ethanolic extract of Centratherum anthelminticum kuntz on fasting glucose of alloxan induced diabetic rats is shown in (table-2) the ethanolic extract significantly $(\mathrm{p}<0.05)$ lowered fasting blood glucose of both normal and diabetic rats. $0.75 \mathrm{~g} / \mathrm{kg}$ dose of ethanolic extract of Centratherum anthelminticum kuntz produced the maximal fall of $29.9 \%$ in normal rats and $39.7 \%$ in diabetic rats.
Diabetic rats (group $2^{\text {nd }}$ ) were found to have significantly increases serum cholesterol. LDLcholesterol, VLDL- cholesterol, and triglycerides level as compared to group 1.HDL- cholesterol was also reduced significantly in diabetic rats. Treatment of ethanolic extract of CA in different doses or glibenclamide significantly preventing the increase in serum cholesterol LDL- cholesterol and VLDLcholesterol serum triglycerides levels as compared to group decreased non significantly in group $2^{\text {nd }}$.treatment with the ethanolic extract of different doses of CA or glibenclamide produced significant increase in HDLcholesterol level as compared to in group $2^{\text {nd }}$. Insulin diabetic rats exhibited significantly higher serum urea level and serum creatinine level as compared to those of group 1.chronic treatment with ethanolic extract of Centratherum anthelminticum and glibenclamide significantly prevented this increase in serum urea and serum creatinine level of group $2^{\text {nd }}$ (Table-3).

From these results, we conclude that ethanolic extract of Centratherum anthelminticum decreased glucose levels, increased insulin level

\section{REFERENCES}

1. Carvalho E. N, Carvalho N. A. S, Ferreira L. M, "Experimental model of induction of diabetes mellitus in rats", Acta Cir Bras, 2003; (18):268-72

2. Handa S.S, Chawla A.C, Maninder A. "Hypoglycaemic Plants review". Fitoterapia 1989; (60):195-222.

3. Holman R.R, Turner R.C, "oral agents and insulin in the treatment of NIDDM", Textbook of diabetes Oxford Black, 1991; 469-470.

4. Ohkubo Y. Kishikawa, H. Araki, E. "intensive insulin therapy prevented the progression of diabetic microvascular complications in Japanese patients with non insulin dependent

diabetes mellitus: a randomized prospective six year study", Diabetes res clin Prac. Pub Med 1995; (28):103.117.

5. Qureshi S.A, Nawaz, A. Udani S.K, Azmi, M.B, "Hypoglycaemic and hypolipidemic activities of Rauwolfia serpentina in alloxan-induced diabetic rats", Int J Pharmacol, 2009; (5):323-326.

6. World Health Organization, "second report of the WHO Expert committee on diabetes mellitus", Geneva, Technical Report Series; 1980; 646-666.

7. Zhang, X.F, Tan, B.K.H, "Antihyperglycemic and antioxidant properties of Andrographis paniculata in normal and diabetic rats, clin Exp Pharmacol Physiol; (2002); 27(29):358-363. 